Blessed are the

\section{Cheesemakers: evidence based policy versus the oral tradition}

\section{Derek Law}

\begin{abstract}
Author
Derek Law has worked in several British universities since 1970 and has published almost 200 book chapters, articles and conference papers. Most of his work has been connected with the development of networked resources in higher education and with the creation of national information policy. Recently he has worked on the use of wireless technology in developing new methods of teaching and learning.
\end{abstract}

Derek is immediate past Treasurer of IFLA; Past president of CILIPS (the Scottish Library Association) and past President of electronic Information for Libraries (elFL), which promotes electronic access to journals for developing countries. He has served on a wide range of national level committees relating to electronic libraries and archives and was directly involved in setting up both the Bath Information and Data Services (BIDS) and Arts and Humanities Data Service projects. He has been the Principal Investigator for 16 research grants from bodies ranging from Economic and Social Research Council to the European Community and is currently working both on digital library issues and virtual universities. He has acted as project reviewer/evaluator for a wide range of international and national bodies.

\section{Scene setting}

"What was that?"

"I don't know. I was too busy talking to Bignose."

"I think it was 'Blessed are the cheesemakers.",

"Ah, what's so special about the cheesemakers?"

"Well, obviously, it's not meant to be taken literally. It refers to any manufacturers of dairy products."

- Monty Python's Life of Brian

\section{Introduction}

The wisdom of crowds is a popular concept at present. It has one basic practical flaw in that the noise of crowds can lead to mishearing, as in the above irreverent mishearing of the Beatitudes.

Brian Perry and the British Library Research and Development Department (BLRDD) were always great believers in applied research, in practitioner research and in collecting the evidence and views of experts. They were committed to the concepts of evidence based practice, practitioner research, capacity building and Delphi techniques, long before these names were invented. They believed in a national research agenda, in creating a pool of researchers, and in topic based cross-sectoral studies involving all types of library and crossdomain research involving all parties in the information chain. They encouraged conferences for the dissemination and sharing of research and fostered international links long before budget airlines made travel a commonplace. After Perry retired, BLRDD was succeeded by the Library and Information Commission and by the British Library Research and Innovation Centre (BLRIC), both of which were imbued with the same attitudes and similar goals. BLRIC merged with LIC, but the two were soon replaced. With the ending of the LIC came the ending of that chapter of building a national research agenda and a pool of researchers.

\section{Brian Perry}

The bare facts of Brian's career are simple to recount. He was born in Exmouth in 1936 and as a young adult moved to London where he studied biology at King's College London. As a graduate he became an indexer with Department of Scientific and Industrial Research and began to climb the rungs of his career by running its North East Office. He became involved in research funding for library and information science from 1965, first at the Office for Scientific and Technical Information (OSTI) and then from 1975 at the Research \& Development Department of the newly formed British Library, whose Director of Research he became 
Blessed are the Cheesemakers

Derek Law

in 1984, heading the department which he ran until his retirement in 1995. In other words his career entirely preceded the World Wide Web, although in many ways it anticipated it. The programmes of BLRDD allowed

experimentation and exploration of a huge range of computing and telecommunication tools and services and also helped to build and encourage a framework of co-operation - often crosssectoral co-operation so sadly lacking today. Brian retired in 1995 and moved back to Exmouth first to help his ageing stepmother and then to enjoy his wide-ranging book collection as his health progressively failed. To the last he kept in regular touch with the wide circle of friends he had made in his career. He died earlier this year and his genial and gossipy companionship is much missed.

\section{BLRDD Objectives}

BLRDD began in an era where formal objectives and visions and missions were not often articulated. However by 1982, as belts began to tighten, its advisory committee (ACORDD, 1982) felt it worth setting down what BLRDD objectives were:

- To identify priority research areas and provide support in those areas through funding research and demonstration projects

- To disseminate the results of research

- To support the national and international exchange of research experience

- To co-ordinate research within the BL

- To encourage the development of research expertise.

The fourth of these objectives - to co-ordinate research within the British Library was essentially an in-house activity beyond the scope of this paper, but in the other areas BLRDD delivered richly. However before considering its progress against these objectives, it is worth outlining the financial background against which it operated.
Library \& Information Research (LIR) Volume 31 - Number 97 - Special Edition 2007

\section{BLRDD Budget and role}

In its final year BLRDD had a core budget of some $£ 1.6$ million for grants and awards. This figure had been progressively eroded by inflation and it has been estimated that had it kept terms with inflation a figure of $£ 3.7$ million pounds would have been needed by 1995 .

However despite this poverty of budget, its reputation was immense and it acted as a sort of mini Research Council for LIS studies. This was no small feat as that rich period of research activity allowed BLRDD to act as midwife to the new digital world long before the great spurt in funding brought on by the Follett Report and the People's Network. Transforming library research and indeed library schools, from book based humanities activity to computer comfortable science activity was no mean challenge. BLRDD was often asked to manage sums of money on behalf of others and it was able to leverage its own funds as a small element of a larger pot. Funds as varied as the BNB Research Fund, JISC, the LASER Foundation, Wolfson, and various earmarked sums were linked to BLRDD in various ways.

It is perhaps fruitless to identify exactly how much is spent on LIS Research, since this would require some definition of where the boundaries lay. However there are some markers which illustrate just small BLRDD funding was, yet how significant BLRDD was. One might look at the level of funding reported in the last three Research Assessment Exercises. 


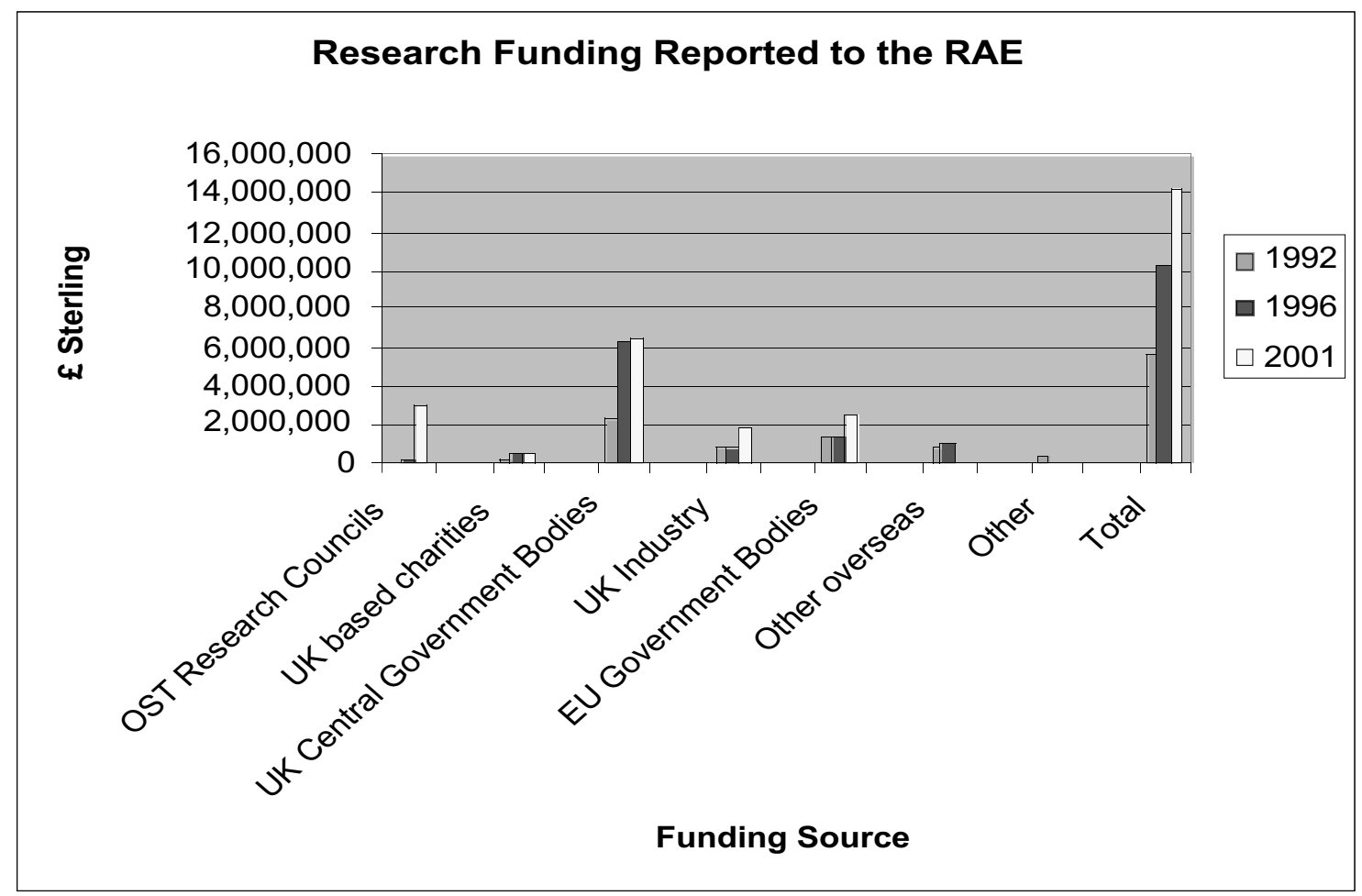

Table 1: Research Funding in Information Science

The range of institutions submitted has changed, making detailed analysis difficult, but some tentative general conclusions can be reached. The total expenditure has risen from just under $£ 6$ million to over $£ 14$ million. Conclusions which might be drawn are:

- Government Funding is static at best (ie LIC, MLA, DCMS)

- The growth in Research Council funding means a shift away from practitioner and applied research to "real" research

- By the same token there is reduction in crosssectoral and cross-domain research as the Research Councils are effectively HE dominated

- The growth in European funding is perhaps unlikely to continue as there is no longer a specific libraries programme

- Thus the large growth in overall research funds conceals a fall in applied research.

The figure reported to the RAE translates to about $£ 3$ million a year. A review conducted in 1999 gave a much larger overall figure for LIS research, development and related activities as $£ 20 \mathrm{~m}$ per year. However this was at the apogee of JISC investment and covered the funding of services and products and items such as digitisation and access funds as well as research. LIC arguably remained the prime source for basic blue sky

\section{Developing research expertise}

BLRDD was also clear that its role extended to creating a pool of researchers and it ensured that research training was both rigorous and available. It is easy to forget that its role here began before the RAE when the principle task of the library schools was professional training and fewer than half of lecturers had published research papers (Meadows, 1994). As well as its support for the Transbinary Group on Librarianship and Information Studies (TYGLIS) in 1985, which aimed to pull the profession into an electronic world, Perry and his staff worked tirelessly to share the vision of a national research agenda and to populate the profession with librarians turned researcher. Small travel grants were used to good effect to expose young librarians to fresh, sometimes international thinking. Brian himself was a genial and congenial mentor and friend. Modesty has forbidden their display, but today's main speakers boast a rich haul of half a dozen doctorates, half a dozen chairs and half a dozen 
honorary degrees. I suspect most of them would agree that Brian paid at least some hand in setting them on the path which made this appropriate recognition for their work. They began and developed what would now be called CPD courses for middle managers, again in part to demonstrate the importance of evidence based practice.

\section{Support for infrastructure}

Perry was also clear on the need to provide the infrastructure which supported research. He was instrumental for example in setting up the European Association for Library and Information Education and Research. As already mentioned, BLRDD was also asked to service the TYGLIS Group, which helped to shape the nature of professional training, which was at a point of radical change.

But perhaps most notably BLRDD used Research Centres as a multi-purpose tool. They allowed focus on a particular topic (typically cross-sectoral), they established a body of researchers in general, but also in specific areas and they provided a space that practitioners could relate to. But this was no old boys club. After a period the topic would move off the priority list, funding would be withdrawn and the fledgling centre left to thrive or wither. The examples of this approach are numerous, but mention might be made of:

- CRUS - Centre for Research on User Studies

- CLAIM - Centre for Library and Information Management (working on performance measures)

- NRCd - National Reprographic Centre for documentation (later Cimtech)

- LISU - Library and Information Statistics Unit

- LITC - Library Information Technology Centre

- CCR - Centre for Catalogue Research

- UKOLN - UK Office of Library Networking

A quite different and unusual step was his championing of a particular technology. He had a prescient view of user involvement in information seeking and chose to champion CDRom at a time when it was not obvious that this would prove such a major format. He worked against the trend to develop a commercial product in Whitaker's Book Bank CD-Rom.

\section{Dissemination}

BLRDD saw one of its prime missions as the dissemination of research. It was an area in which the BLRDD name could be used to maximum advantage, leveraging funding from other bodies to bring broad groupings together. Burnard (1989) gives an excellent example of this practice in a report which demonstrates all the things BLRDD aspired to $-\mathrm{a}$ wide and eclectic audience, crossing national and discipline boundaries, leveraging resource with partners, Brian's humour.

All academic communities define themselves partly by regular gatherings dedicated to self examination; the community of information scientists, i.e. those skilled in the management and exploitation of library and analogous resources in research, is no exception. During the seventies there had been a regular series of such gatherings known as the Cranfield Conference. These having now fallen into desuetude, when Brian Perry, head of the British Library's Research and Development Department, welcomed us to this reborn version he naturally proposed that it should be called Not the Cranfield Conference. The four day event, jointly sponsored by the British Library, the University of Pittsburgh's Department of Library Science, and the UK Computer Board, attracted a small but agreeably heterogenous audience. Attendance at sessions averaged 60 from a total registration of just under a hundred, largely composed of information science professionals, computerate librarians, human factors computing theoreticians, a sprinkling of civil servants and various other varieties of professional research support people, drawn fairly even handedly from universities and polytechnics, with even a few token representatives of industrial concerns such as Shell. Although the British formed the majority, followed by the Americans and the French, several other countries were represented including Sweden, Eire, Canada, Netherlands, Turkey and Bophutatswana.

Or consider this blurb for a 1991 publication of conference proceedings on research policy in librarianship and information science, bringing 
together a galaxy of the talents, again with shared funding and with the intention of creating a research agenda and ensuring an adequate pool of talent to conduct the research. Here too we see a strong mix of practitioners and researchers from the whole range of information science:

Research policy in the fields of librarianship and information science is being shaped by a number of forces, and for some time these have required a systematic analysis. This volume, arising from a conference sponsored by the British Library, the Library and Information Research Group and the Public Libraries Research Group, offers the distilled expertise of senior members of the information profession who have extensive experience of research and development.

Together with representatives of the major funding agencies, they present here a comprehensive review of the important issues affecting research policy, focusing on the advantages and inadequacies of the present systems, the role of government in library/information research and the coordination of research in the field, issues of quality and evaluation in this research, research performance, application and utility, manpower issues and the calibre of research workers. Contributors include Maurice Line, Brian Perry, John Martyn, Tom Wilson, John Myers, Geoff Ford, Harry East, Lynne Brindley, Peter Taylor, John Allred, Pat Coleman, Bob McKee, Michael Brittain, Philip Bryant, Nigel Gardner, Paul Ayscough and David Streatfield.

(Harris, 1991)

There was also a strong publications programme. As well as research reports, a string of monographs was produced jointly with Bowker Saur. It was clear that BLRDD intended research outcomes to be available to the community and not just in some rarefied way to other researchers. Another good example of this was the encouragement of VINE (Very Informal Newsletter) produced by the LITC and essential reading for anyone interested in Library IT.
Library \& Information Research (LIR)

Volume 31 - Number 97 - Special Edition 2007

\section{Support for cross domain and cross- sectoral policy development}

While most BLRDD funding went to university departments and centres, its focus was much broader. As has been shown, most of the centres were topic not sector based. Unsolicited proposals typically covered more than half of the annual funding and by 1991, more than fifty grants had been made to public libraries. Policy and future gazing papers were as much concerned with public libraries as other areas. None the less, the low level of research on public libraries was a semi-permanent concern. The BLRDD Research Bulletin, No. 9, Autumn 1993, described current problems in discovering and encouraging research proposals - and described the reasons. It stated that "[BLRDD] is anxious to find a way of increasing its involvement in public libraries" and went on to list a number of significant areas where research would be beneficial. Perhaps its most significant work was to be on IT, which was certainly cross-sectoral!

\section{International adventures}

BLRDD saw international links as crucial to the development of healthy LIS research. A key element in this was to be Europe and again the importance was seen of shaping the agenda and not just responding to it. The National Focal Point was set up in BLRDD and proved a source of advice and help. Critically, when planning meetings were held in Brussels or Luxembourg, BLRDD ensured that the necessary civil servants - often from the Department of Trade and Industry - were accompanied by a practitioner in order to provide a dose of pragmatism to agendas. This approach was much valued in the EU, as evidenced by the fact that the Libraries Programme proposed in the Telematics chapter of the Fourth Framework Programme was effectively written by two British librarians, working with a British born Dutch consultant. A total of 49 projects (including accompanying measures) were funded under this programme, receiving $€ 29$ million in total and with a very strong British presence. The Libraries Programme is widely acknowledged as having 
been a huge success. Before the programme European partnerships were unusual, now they are commonplace.

BLRDD also supported a range of bilateral meetings, notably the Anglo-French, AngloGerman and Anglo-Nordic Seminars. These were always popular and successful and have again led to a series of ongoing relationships and partnerships. Similar efforts were made in North America and led to the Glenerin Declaration with the USA and Canada, although it has to be said that this proved much less productive than European links.

Brian Perry was himself fascinated by Japan and a series of projects and visits were both enjoyable and productive although sadly not surviving the demise of BLRDD.

\section{Disappearing Resource}

The research world became quite complex after the retirement of Brian Perry in 1995, and it is perhaps necessary to give a general overview of the 1995-2000 period before returning to the specific bodies. BLRDD was succeeded by the British Library Research and Innovation Centre (BLRIC), which continued to control the research budget of $£ 1.6$ million. At the same time the Library and Information Commission was set up and given responsibility for national research strategy, but with only a tiny budget of its own. This was seen as a more or less stable transition, since LIC and BLRIC worked closely together. For example BLRIC's document Research plan April 1998 to March 2001 (BLRIC, 1997) was developed in close consultation with the LIC and reflected its research framework. A budget of $£ 1.9$ million each year was sought to deliver the research plan. In April 1999 the perhaps inevitable happened and the research-funding activities and resources of BLRIC were transferred into LIC. This gave LIC a major increase in research funding as well as a significant increase in the scope of research, adding "practice" oriented, "blue skies" and basic research to the original policy-led remit (Shepherd, 1999). Within twelve months LIC was absorbed into the new and unwelcome
Museums Libraries and Archives Council in another major energy absorbing change. The change brought a frenzied bout of reviews consultations and self examination and a complete policy vacuum on research. The confusion was compounded by the immediate and fatuous renaming of MLAC as Re:source, so that its credibility was fatally undermined before it had a chance to establish itself. The MLAC/Re:source Manifesto (2000) promised that a new research strategy would be published in December 2000 which "is likely to include a substantial element of impact research, since the assessment of particular policies and initiatives will be crucial to the future success of the sector. The strategy will propose new streamlined procedures for commissioning research". The Re:source Chief Executive Neville Mackay indicated that their approach to research would be developed in the light of responses to two consultation documents: the report $A$ review of research priorities and practice for the Museums, Libraries and Archives Council (MLAC) by Professor John Shepherd, setting out ideas for the development of MLAC's research programme, and Consultation on the work of the Museums, Libraries \& Archives Council, describing the vision for MLAC, its strategic objectives, the main elements of its work programme, and the processes for carrying it out. (Ashcroft, 2000). It is unclear that an approach to research was ever agreed. If so it was not disseminated. Nor apparently was the $£ 1.6$ million for LIS Research.

It was a sad end to a glorious and productive chapter.

\section{BLRIC}

BLRIC was set up in 1995 with the mission of advancing library and information services in the UK, which it energetically pursued until its merger with LIC in March 1999. The staff who had managed research grants were given a wider remit as "research analysts" with the objectives of promoting their hard-earned knowledge to and being more engaged with the user community. BLRIC was a new body, but it adopted both the concerns and the best practices of its predecessor. As an example it issued a call 
in partnership with the Public Libraries

Research Group, to build on earlier work on research in public libraries. The Centre for Information Research and Training (CIRT) at the University of Central England had a funded project called Developing Research in Public Libraries. The specific areas of public library research addressed by this project were:

- developing research expertise

- encouraging practitioners to undertake and act on research and to develop effective dissemination channels for research

- developing a distance-learning course on research skills for practitioners.

The project also aimed to develop a long-term strategy to ensure that research expertise and dissemination methods developed could continue beyond the end of the project. In addition The project team devised a three-day course in research skills for public librarians, which was run in eight locations across the UK, reaching over 120 participants. From this a distance-learning course was developed and undertaken by some 30 librarians. (CIRT, 1999)

It further adopted continuity of method. One of its final acts was participation in the Warwick 2 Seminar on Digital Preservation. This brought together experts and stakeholders from various sectors under the banner of the CEDARS Project (CEDARS, 1999) as a way of defining the route forward for this area of research.

In its final year of operation it bequeathed to LIC a lively programme of work:

Digital Libraries:

- evaluation of a web site accessing books and stories

- internet technologies for community information

Information Retrieval:

- concept based automatic abstracting

- uncertainty in information seeking

Library Co-operation:

- cross sectoral library co-operation through staff training

- development of a prototype common interface to public information
Preservation of and Access to the

Recorded Heritage:

- security in libraries and archives in historic buildings

- preservation management training

Public Libraries:

- developing research expertise in the public library sector

- a public library workforce study

Value and Impact of Libraries

- public libraries in the National Year of Reading

- barriers to access to libraries for lifelong learning

Continuity and a smooth transition was expected since the merger of LIC and BLRIC had been planned and expected for some time.

\section{Library and Information Commission: establishment and aims}

The Library and Information Commission (LIC) was established in 1995 to be a national focus of expertise on the library and information sector for England and Northern Ireland. It was a successor to the Library and Information Services Councils for the Home nations, which had a public library and information services role, but with a different, larger and UK-wide remit. As well as a general remit to advise government, LIC was charged with a number of specific tasks, including the strategic roles which BLRDD had performed:

- to develop a national research strategy for the LIS sector;

- to manage the UK National Focal Point for the Telematics for Libraries Programme;

- to advise Government on the feasibility of a national information policy; and

- to recommend ways to increase the value for money from publicly funded library and information services through co-ordination and co-operation within the LIS sector. 
Blessed are the Cheesemakers

Derek Law

\section{LIC Research}

The Research Committee was charged with developing a UK national strategy for research and development in the library and information field and to implement and maintain this strategy in co-ordination with the research programme of the British Library and other relevant bodies. It produced a report -

Prospects: a strategy for action (Library and Information Commission Research Committee, 1997) - which identified how it would proceed. It proposed to continue with open calls for proposals under a three year rolling programme of strategic research projects. The intention was to fund about ten projects a year which would be selected from the three core themes. It was clear that the focus on applied research was to continue and there was specific mention that proposals might include demonstrator projects which followed up previous research.

Initially, the LIC had funded only policy-led research in order to advise government. With a budget of about $£ 150,000$ and the capacity to support only three or four projects, most of its research was commissioned by tender and carried out by consultants. These included projects such as: the role of libraries in lifelong learning; the digitisation of content in local authorities; library/cable based communication provider partnerships; and underpinning skills for knowledge management. Several significant policy reports were produced.

- REVEAL: The National Database of Resources in Accessible Formats was aimed at highlighting the need to do more for the visually impaired

\section{- Full Disclosure: Releasing the value of} library and archive collections considered the desirability of major retrospective catalogue conversion

\section{- Virtually New - Creating the Digital} Collection looked at digitisation

- 2020 Vision was an attempt to envision the challenges which would face libraries and practitioners in the new millennium
Library \& Information Research (LIR) Volume 31 - Number 97 - Special Edition 2007

- New Library: the People's Network. A major proposal to bring public libraries into the forefront of the public service by creating a national network

The merger with BLRIC had been well trailed and was a natural evolution of the close working of the two bodies. Not only did the transfer of core funding take place. What seemed a cornucopia of additional earmarked funding was also promised.

- the administration of the DCMS/Wolfson Public Libraries Challenge Fund for ICT in public libraries (currently involving expenditure of $£ 3$ million

- the administration of a $£ 200,000$ fund to improve library services to blind and partially sighted library users

- the new library prize for Ingenious and Creative use of Technology in public libraries

- the British National Bibliography Research Fund (BNRBF) with a budget of $£ 40,000$ for 1999/2000, the BNBRF supports research for small-scale projects

\section{LIC principles and practice}

It is perhaps worth concluding by looking at what the LIC as a whole stood for and achieved (Haines,1998). As well as a Research Committee it had an International Committee. It provided advice on issues related to the impact of European Union policies on the UK library sector as well as monitoring and advising on information policy developments elsewhere, particularly in the G8 countries. This Committee also oversaw the UK National Focal Point. The principles it adopted flowed naturally from the work of BLRDD - perhaps unsurprising since many of the Commissioners had had a close relationship with that body! They included:

\section{- Taking a holistic approach}

There was a conscious effort to avoid a sectoral view and to focus on topics. The emphasis was on cross-sectoral projects or on projects where the lessons were transferable. 


\section{- Focusing work at the national and international level}

As a national advisory body, the LIC focused its attention on national UK-wide strategic issues. The LIC would only advise on local issues if it could be demonstrated that the issues were generalisable.

\section{- Building Partnerships}

Alliances with national co-ordinating and professional bodies were important in promoting a UK wide approach to the Information Society. Liaison with European organisations offered the potential for harmonisation of national with European policy developments. Liaison with organisations outside Europe, enabled the sharing of experiences and understanding of the global context.

\section{- Consulting and disseminating results widely}

All advice to Government was given on the basis of as wide a process of consultation with the LIS community and the public as possible. The time-frame might necessitate focused consultation, emphasising the importance of partnerships. The LIC's policy was to disseminate information on its activities as widely as possible through conferences and seminars, the Internet, and publications.

These principles offer a glimpse of the way ahead.

\section{Lessons for the future}

The story for the future is taken up by Peter Brophy and I will not trespass on his territory. However I have been asked to draw some lessons for the future. Let me say one thing however. The overarching ambition of both BLRDD was to create and then support a national research agenda. The word research does not appear on the MLA Home Page and it does not appear to have a research committee. So my lessons for the future may be seen not just as applauding what was there before - no doubt imperfectly - but as seeing what is missing at present.
- The desirability of cross-domain research

- Libraries, computer scientists, industry, government

- The desirability of cross-sectoral research

- Public, university, special, government, health etc

- The desirability of evidence based practitioner research

- The desirability of policy research and future studies

- The desirability of international research and partnership

- Shaping the agenda not responding to it

- A strategic research programme for libraries

And above all the dissemination and sharing of research findings.

\section{Conclusion}

The works of BLRDD and, implicitly, Brian himself are recorded in Meadows' elegant history of the Department (Meadows, 1994). The Library and Information Commission had a shorter span, but its work is recorded in print by Haines (Haines, 1998). It was succeeded by the deeply unloved Re:source, which has been almost entirely obliterated from both history and the Internet, reverting to its proper title of the Museums, Libraries and Archives Council (MLA), whose home page contains neither the words Re:source nor research. But the need for a research agenda and the history of that research agenda refuse to go away. There is a certain irony in the fact that the LIC information is not held on the MLA website but on the UKOLN website. And who set UKOLN up? Yes the old cheesemaker himself, Brian Perry. 


\section{References}

ACORDD (1982) Report of the ACORDD Working Party on priorities (ACORDD 82/2).

Ashcroft, Linda \& Mclvor, Stephanie.(2000) LIS research and publishing: the forces of change Library Review 49(9) Pp. 46I-469.

British Library R\&D Department (1993), Research Bulletin, No.9.

BLRIC (1997) Research plan April 1998 to March 200 I.

BLRIC/LIC (1999), Review of Research Funding for LIS.

Burnard, Lou (1989). Information Technology and the Research Process. Cranfield Institute of Technology, 1821 July 1989 Conference report http://2 16.239.59.1 04/search?q=cache:al6jFIzMv0 AJ:users.ox.ac.uk/ lou/reports/8907cranf.xml+B urnard+Bophutatswana\&hl=en\&ct=clnk\&cd $=$ I \& gl=uk [viewed on February $14^{\text {th }}$ 2007]

CEDARS (1999)

http://www.leeds.ac.uk/cedars/OTHER/warwickrec.htm [viewed on February 14 ${ }^{\text {th }}$ 2007]

CIRT (1999) Completed Projects. Developing Research in Public Libraries http://www.ebase.uce.ac.uk/cirtarchive/projects/past/dripl.htm [viewed on 14 ${ }^{\text {th }}$ February 2007]

Haines, M. (1998) The Future of libraries in the information society: The UK Library and Information Commission's vision. Alexandria I0(2): |3|-| 42.

Harris, Colin. (1991) Research Policy in librarianship and Information Science. Cambridge:Taylor Graham.

Library Association (1998) The comprehensive spending review: a new approach to investment in culture. The response of The Library Association.

Library and Information Commission Research Committee (1997) Prospects: a strategy for action. http://www.ukoln.ac.uk/services/lic/research/ [viewed on February 14 ${ }^{\text {th }}$ 2007]

Martyn, John et al. (1990) Information UK 2000 (British Library Research Series) London: Bowker Saur.

Meadows, Jack. (1994) Innovation in Information:Twenty Years of the British Library Research and Development Department (British Library Research Series) London: Bowker Saur,
Library \& Information Research (LIR)

Volume 31 - Number 97 - Special Edition 2007

MLAC/Re:source (2000) Manifesto.

Shepherd, J. (1999) A review of research priorities for Museums, Libraries and Archives Council (MLAC) London, DCMS.

Sumsion, John (1994) Strategic research areas and possible research models for UK public libraries. Library Review 43 (4) Pp. 7-26. 